\title{
INDONESIAN STUDENTS' ANXIETY TO WRITE IN ENGLISH AS A FOREIGN LANGUAGE ACROSS GENDER AND EDUCATIONAL LEVELS
}

\author{
Herri Mulyono, Anggi Rizky Liestyana, Silih Warni, \\ Gunawan Suryoputro, Sri Kusuma Ningsih \\ University of Muhammadiyah Prof. DR. HAMKA, Indonesia \\ E-mail: hmulyono@uhamka.ac.id, aanggirizky@gmail.com, silihwarni@uhamka.ac.id, \\ gunawan_suryoputro@uhamka.ac.id, sri_kusuma@uhamka.ac.id
}

\begin{abstract}
This survey explored the level and types of anxiety expressed by Indonesia students in writing in English as a foreign language anxiety across gender and educational levels. To this end, 221 foreign language (FL) students from three levels of educations, i.e. lower-secondary school, upper-secondary school and university, were surveyed on voluntary basis where they were asked to complete 22 items of a Second Language Writing Anxiety Inventory (SLWAI) questionnaire. Two statistical analyses, Rasch Analysis and ANOVA, were performed to examine the quantitative data. The findings showed that all students experienced writing anxiety in FL learning, many experiencing a moderate level of anxiety. Furthermore, students' writing anxiety was not influenced by gender and educational levels. Indeed, students across all education levels reported experiencing somatic anxiety, avoidance behaviour and cognitive anxiety, with avoidance behaviour being the most common form of anxiety. In conclusion, it is recommended that helping students to develop a positive perception of their FL writing is crucial in addition to helping them develop their writing skills.
\end{abstract}

Keywords: foreign language anxiety (FLA), foreign language (FL) learning, Rasch model, writing anxiety.

\section{Introduction}

In the foreign language learning, anxiety is one of psychological factors that plays a pivotal role in determining the success of students' learning and performance (Awan, Azher, Anwar, \& Naz, 2010; Bekleyen, 2009; Hewitt \& Stephenson, 2012; Mulyono, Ferawati, Sari, $\&$ Ningsih, 2019). Anxiety to learn and use a foreign language, also known as foreign language anxiety (FLA), reflects a complex dimension of learners' self-perception, their beliefs, feelings as well as behaviour during the foreign language (FL) learning process in the classroom (Horwitz, Horwitz, \& Cope, 1986). Learners with FLA tend to feel anxious and apprehensive during their FL learning, which frequently leads to learning difficulties, becoming forgetful, and exhibiting disruptive and avoidance behaviour (Cheng, 2004b; Horwitz et al., 1986; Mulyono et al., 2019; Ningsih, Narahara, \& Mulyono, 2018).

The term writing anxiety in foreign language learning, has been mostly restricted to the academic context and has been mainly concerned with individuals' perceptions. Writing anxiety manifests as an emotional form of fear, loss of self-confidence and demotivation among 
Herri MULYONO, Anggi Rizky LIESTYANA, Silih WARNI, Gunawan SURYOPUTRO, Sri Kusuma NINGSIH. Indonesian students' anxiety to write in English as a foreign language across gender and educational levels

PROBLEMS

OF EDUCATION IN THE $21^{\text {st }}$ CENTURY Vol. 78 , No. 2, 2020

250

individuals to write a composition (Guneyli, 2016). In the former, writing anxiety is often provoking students' belief about their own writing capability (Cheng, 2002). It also contributes to the loss of neutrality in expression and misses the text's integrity (Guneyli, 2016). Wynne, Guo, and Wang (2014) perceive writing anxiety as feelings of individuals' insecurity arising from the inhibiting thoughts in mind which are conflicting themselves. They posit 'writing anxiety' as writer's block, which was intended as a difficulty in expressing ideas into a proper writing. For instance, when students are asked to write under time pressure, they will find it difficult to interpret their ideas in writing. Psychologically, such a condition is perceived to be normal along with the lack of comprehension (Cheng, 2004a; Ekmekçi, 2018; Özkan \& Da, 2015).

In the context of academic competence, writing anxiety plays a pivotal role to stimulate students on improving their language competence and writing skills. Teachers therefore must provide some valuable insights dealing with how to reduce the effect of anxiety to ensure the cognitive, behavioural, and motivational engagement of students (Özkan \& Da, 2015). This can be accomplished by reducing negative feedback on learners' performance and enhancing possibilities for forming a suitable and positive perception of their language skills (Yan \& Wang, 2012). Building a comfortable and relaxing learning atmosphere is also critical to helping learners achieve confidence and gradually overcome the fear of writing anxiety (Yan \& Wang, 2012). Teachers' failure to prevent their students from experiencing writing anxiety may result in students' inability to explore and express their own thoughts and accordingly may restrict them from producing high quality writing (Cheng, 2002).

Much of the literature regarding second or FL writing (Cheng, 2004a; Ekmekçi, 2018; Ho, 2016; Özkan \& Da, 2015; Rezaei \& Jafari, 2014) has discussed several factors that promote anxiety in writing a target language composition among students. Some authors (e.g. Daud, Daud, \& Kassim, 2016; Gupta, 1998) believe that writing anxiety emerges from students' individual perceptions that the FL writing skill is highly complex and difficult to learn. Students also perceive that successful writing requires a high level of linguistics competence (see Özkan \& Da, 2015; Rezaei \& Jafari, 2014) in addition to students' self-expression, the flow of ideas for writing, self-confidence, and their enjoyment of second language writing (Basturkmen \& Lewis, 2002).

In addition, working under time constraints, which is frequent in an academic writing environment, is also viewed as another source of writing anxiety. Özkan and Da (2015) believe that students would not be able to explore their thoughts in FL writing under time constraints. Often time constraints can impact on their writing, resulting in grammatical mistakes, inappropriate vocabulary use, and short compositions. In this context, writing anxiety leads students to write inadequate messages, as they write shorter and simpler passages (Özkan \& Da, 2015). More importantly, many studies have suggested that highly-anxious students produce low quality writing, with poor attainment in standardized writing tests (Daly, 1978; Daly \& Miller, 1975).

Furthermore, Martinez, Kock, and Cass (2011) identify two other contributing factors to EFL writing anxiety, including high expectation of students' writing across schools and the university curriculum demand. They argue that many universities have been implementing writing into their fundamental course requirements. Students are required to produce pieces of text that meet particular standard of academic writing. Students who fail to meet such a standard may be advantaged to acquire their course attainment. 
Herri MULYONO, Anggi Rizky LIESTYANA, Silih WARNI, Gunawan SURYOPUTRO, Sri Kusuma NINGSIH. Indonesian students' anxiety to write in English as a foreign language across gender and educational levels

\section{Research Problem}

PROBLEMS

OF EDUCATION

IN THE $21^{\text {st }}$ CENTURY

Vol. 78, No. 2, 2020

251

Although studies of FL writing anxiety abound in the literature (Cheng, 2002, 2004b; Daud et al., 2016; Ho, 2016; Negari, 2012; Özkan \& Da, 2015; Rezaei \& Jafari, 2014), until recently, FL writing anxiety is still underexplored in Indonesian FL learning classrooms. Conducting a research regarding writing anxiety will be significant in informing Indonesian EFL classroom teachers about why students feel anxious about writing in a FL and accordingly, teachers can plan their classroom instruction to address this anxiety.

\section{Research Focus}

The current study attempted to explore the extent to which Indonesian EFL students experience anxiety in writing English as a FL, addressing two research questions as below:

1. Do Indonesian EFL students at lower-secondary school, upper-secondary school and university experience FL writing anxiety?

2. To what extent do the Indonesian EFL students experience FL writing anxiety across gender and educational levels?

\section{Research Methodology}

\section{General Background}

A survey research was adopted to address the two research questions as discussed earlier. Cohen, Manion, Morrison, and Bell (2018) argue that survey enables researchers to gather quantitative data at a particular point at time allowing them either to describe or identify the nature of particular phenomena in a society. The utilisation of survey benefited the current study as it helped the researcher to target wider participants and generate numerical data that provided "descriptive, inferential and exploratory information" (Cohen et al., 2018, p. 334).

\section{Sample}

A total of 221 students across educational levels, i.e. university (U), upper-secondary school (US) and lower-secondary school (LS) from both private and public education institutions in Indonesia, participated in the study on a voluntary basis and their demography is presented in the following Table 1:

\section{Table 1}

Students' demography

\begin{tabular}{|c|c|c|c|c|c|c|c|c|c|}
\hline & & \multicolumn{6}{|c|}{ Education } & \multicolumn{2}{|c|}{ Total } \\
\hline & & \multicolumn{2}{|c|}{$\begin{array}{l}\text { Lower-secondary } \\
\text { School }\end{array}$} & \multicolumn{2}{|c|}{$\begin{array}{l}\text { Upper-secondary } \\
\text { School }\end{array}$} & \multicolumn{2}{|c|}{ University } & \multirow[t]{2}{*}{$N$} & \multirow[t]{2}{*}{$\%$} \\
\hline & & $\mathrm{N}$ & $\%$ & $\mathrm{~N}$ & $\%$ & $\mathrm{~N}$ & $\%$ & & \\
\hline \multirow{2}{*}{ Gender } & Male & 20 & 31.33 & 21 & 32.8 & 16 & 17.2 & 57 & 25.8 \\
\hline & Female & 44 & 68.8 & 43 & 67.2 & 77 & 82.8 & 164 & 25.8 \\
\hline
\end{tabular}


Herri MULYONO, Anggi Rizky LIESTYANA, Silih WARNI, Gunawan SURYOPUTRO, Sri Kusuma NINGSIH. Indonesian students' anxiety to write in English as a foreign language across gender and educational levels

PROBLEMS

OF EDUCATION IN THE $21^{\text {st }}$ CENTURY Vol. 78, No. 2, 2020 252

The English proficiency amongst the student participants varied, from elementary level up to advanced one. English It is important to acknowledge here that English in Indonesia is taught as a foreign language.

\section{Instrument and Procedures}

To obtain the data regarding EFL students' writing anxiety, Cheng's (2004a), a Second Language Writing Anxiety Inventory (SLWAI) was adopted and distributed to the participants. SLWAI is a 22-item questionnaire developed to examine the level and types of anxiety that students experience, with the items classified into three subscales including somatic anxiety, avoidance behaviour, and cognitive anxiety. Somatic anxiety (SA) includes inventory items that relate to students' increased psychological arousal (items no 2, 6, 8, 11, 13, 15, and 19), avoidance behaviour (AB) comprises items (no 4, 5, 10, 12, 16, 18, and 22) that indicate students' avoidance behaviour of writing English composition, and finally, cognitive anxiety (CA), "a subjective component that deals with the perception of arousal and, in particular, worry or fear of negative evaluation" (Cheng, 2004a, p. 325) was assessed by item number 1, 3, 7, 9, 14, 17, 20, and 21. Each subscale item in the SLWAI was developed in the form of a 5-point Likert scale labelled as SA (strongly agree), A (agree), N (Neutral), DA (disagree) and SDA (strongly disagree). Cheng (2004a) observed that the reliability of the original instruments was high (Cronbach's coefficient $\alpha$ was .98) and validated using factor analysis (see Cheng, 2004a for futher discussion on the instrument validation).

In addition to SLWAI items, student participants were also asked to provide demographic information in the questionnaire including gender, age, province and educational levels. The questionnaire was translated into Bahasa Indonesia by two scholars to ensure its readability. Then, the wordings of the translated questionnaire were reread and revised to ascertain students' understanding of all items and for further Rasch analysis.

\section{Data Analysis}

The SLWAI was developed in an online format to ease distribution and to target a wider range of participants (Ningsih et al., 2018). More importantly, the online inventory format enabled the automated data collection that eased further data analysis (Wright, 2010). The collected data then were analysed in three stages of statistical analysis. First, the raw data were tabulated and converted into logit (logarithm odd unit) to maintain an equal interval within a linear scale (Linacre, 2018). Second, Rasch analysis was performed using Winstep 4.3.4 software to ascertain the internal consistency of inventories, and to evaluate the distribution and the quality of responses input of the participants. Third, 221 records were analysed using ANOVA to examine interactions between demography aspects, such as gender and education levels and the subscale dimensions.

\section{Research Results}

\section{Instrument Reliability}

The reliability of SLWAI scale was examined on the basis of the person and item output. As shown in Table 2, the result of Rasch analysis showed that the person reliability was at .91 with the Cronbach's $\alpha$ at .95. The item reliability was shown at .98 and the Cronbach's $\alpha=.95$ of all the person and item subscales were reported higher than .90 , indicating that the inventory and its subscales exhibit an excellent reliability level (Kline, 2013). In other words, the results suggest that the person and the attribute items were reliably interacted and accordingly had drawn the conformity between the person and the items. 
Herri MULYONO, Anggi Rizky LIESTYANA, Silih WARNI, Gunawan SURYOPUTRO, Sri Kusuma NINGSIH. Indonesian students' anxiety to write in English as a foreign language across gender and educational levels

Table 2

Internal consistency of SLWAI and its subscales

\begin{tabular}{ccccc}
\hline & Mean & Separation & Reliability & Cronbach's a \\
\hline Person & 68.2 & 3.15 & .91 & .95 \\
\hline Somatic Anxiety & 20.8 & 2.33 & .84 & .97 \\
\hline Avoidance Behaviour & 21.5 & 1.67 & .74 & .97 \\
\hline Cognitive Anxiety & 25.6 & 2.34 & .85 & \\
\hline Item & 684.9 & 7.16 & .98 & \\
\hline Somatic Anxiety & 662.3 & 7.83 & .98 & \\
\hline Avoidance Behaviour & 679.3 & 9.64 & .99 & .96 \\
\hline Cognitive Anxiety & 709.6 & 4.96 &
\end{tabular}

\section{Students' Levels of Foreign Language Writing Anxiety}

Students' levels of writing anxiety to write in English as a FL were examined through the Rasch person separation coefficient from the participants' responses to the attribute items in SLWAI. In Rasch analysis, person separation can be used to classify and distinguish survey participants. Separation is the signal-to-noise in the calculated data (Boone, Staver, \& Yale, 2014) and the separation coefficient refers to the ratio of the person true population standard deviation (P.SD), the true standard deviation (SD) to the Root Mean Square standard Error (RMSE), and the error standard deviation (Linacre, 2018).

The Rasch analysis resulted in the index of person separation of 3.15 (see Table 2). The separation value of 3.15 (rounded to 3), which is higher than two, presents an excellent level of separation (Boone et al., 2014; Linacre, 2018) and such a value statistically has classified the participants into three groups, namely low anxiety, moderate anxiety and high anxiety. The separation indexes observed in the Rasch analysis reflected that the attribute items had correctly assessed the students' anxiety level when writing in a FL. The three classifications of anxiety levels as found in the current study correspond to earlier studies by Atay and Kurt (2006), and Rezaei and Jafari (2014), except the current study provided a more comprehensive procedure on how the students' levels of anxiety were classified based upon person separation index. Table 3 below details the distribution of students' FL writing anxiety levels.

Table 3

Students' level of foreign language writing anxiety based on their gender and educational

\begin{tabular}{llllllll}
\hline \multicolumn{7}{c}{ Gender } \\
\hline Anxiety level & $N$ & $\%$ & Male (\%) & Female (\%) & LS (\%) & US (\%) & U (\%) \\
\hline Low & 29 & 13.12 & $11(19.3)$ & $18(11)$ & $8(12.5)$ & $9(14.1)$ & $12(12.9)$ \\
\hline Moderate & 159 & 71.95 & $38(66.7)$ & $121(73.8)$ & $44(68.8)$ & $45(70.3)$ & $70(75.3)$ \\
\hline High & 33 & 14.93 & $8(14)$ & $25(15.2)$ & $12(18.8)$ & $10(15.6)$ & $11(11.8)$ \\
\hline Total & 221 & 100 & $57(100)$ & $164(100)$ & $64(100)$ & $64(100)$ & $93(100)$ \\
\hline
\end{tabular}


Herri MULYONO, Anggi Rizky LIESTYANA, Silih WARNI, Gunawan SURYOPUTRO, Sri Kusuma NINGSIH. Indonesian students' anxiety to write in English as a foreign language across gender and educational levels

PROBLEMS

OF EDUCATION IN THE $21^{\text {st }}$ CENTURY Vol. 78, No. 2, 2020

Table 3 above shows that 29 students possessed a low anxiety level (13.12\%, logit value $<-.88), 159$ students had a moderate level of anxiety $(71.95 \%$, logit value between -.89 and $1.09)$, and 33 students were observed to have a high anxiety level $(14.93 \%$, logit value $>1.10)$. Furthermore, $66.7 \%$ of male $(\mathrm{N}=38)$ and $73.8 \%$ of female students $(\mathrm{N}=121)$ experienced writing anxiety at a moderate level. This level of anxiety was also experienced by students from all education levels i.e. LS, US and U. Surprisingly, more than half of the students with a high level of anxiety were studying at secondary schools (58\%). Martinez et al (2011) argue that the requirement of writing essays is frequently applied in university and accordingly, may promote anxiety among university students. However, in the Indonesian secondary education system, the ability to write in a foreign language is one of primary objectives in the national curriculum and the school policy has included FL writing as one of the evaluation subjects, consequently, FL writing examination is a prerequisite for graduation from secondary school. The implementation of this policy at secondary schools may have been the driver of the high level of anxiety among students.

In addition, one-way ANOVA was utilized to examine if anxiety levels significantly differed based on gender and educational levels. Prior to ANOVA calculation, KolmogorovSmirnov (K-S) test was performed to evaluate if the data fitted normal distribution assumption (Field, 2013). K-S test resulted that all data in each group were distributed normally (see Table $4)$.

Table 4

Result of the normality distribution

\begin{tabular}{|c|c|c|c|c|c|c|c|}
\hline & & \multicolumn{3}{|c|}{ Kolmogorov-Smirnova } & \multicolumn{3}{|c|}{ Shapiro-Wilk } \\
\hline & Gender & Statistic & $d f$ & $p$ & Statistic & $d f$ & $p$ \\
\hline \multirow[t]{3}{*}{ SLWAI } & $M$ & .122 & 57 & $.035^{* * *}$ & .833 & 57 & .000 \\
\hline & $\mathrm{F}$ & .070 & 164 & $.046^{* * * *}$ & .972 & 164 & .002 \\
\hline & Educatio & & & & & & \\
\hline \multirow[t]{3}{*}{ SLWAI } & LS & .096 & 90 & $.041^{*+* *}$ & .958 & 90 & .005 \\
\hline & US & .174 & 37 & $.006^{* *}$ & .783 & 37 & .000 \\
\hline & $U$ & .075 & 94 & $.200^{*}$ & .979 & 94 & .143 \\
\hline
\end{tabular}

Table 5

Result of ANOVA calculation

\begin{tabular}{llll}
\hline & $d f$ & $F$ & $p$ \\
\hline Gender & 1 & .919 & .339 \\
Somatic Anxiety & 1 & 2.311 & .130 \\
Avoidance Behaviour & 1 & .000 & .989 \\
Cognitive Anxiety & 1 & $8.552^{* *}$ & .004 \\
& & & \\
\hline Education level & 2 & 1.497 & .226 \\
Somatic Anxiety & 2 & .125 & .882 \\
Avoidance Behaviour & 2 & $8.147^{*}$ & .000 \\
Cognitive Anxiety & 2 & .025 & .975 \\
\hline$p$ at $.001, * * p$ at $.005, * * * p$ at .01 & &
\end{tabular}


Herri MULYONO, Anggi Rizky LIESTYANA, Silih WARNI, Gunawan SURYOPUTRO, Sri Kusuma NINGSIH. Indonesian students' anxiety to write in English as a foreign language across gender and educational levels

PROBLEMS

OF EDUCATION

IN THE $21^{\text {st }}$ CENTURY

Vol. 78 , No. 2, 2020

The calculation of one-way ANOVA as shown in Table 5 resulted that the anxiety levels were not statistically different between male and female students or among secondary schools and university students $\left(F_{\text {gender }}=.919\right.$ with $p=.339, F_{\text {educational level }}=1.497$ with $\left.p=.226\right)$. The findings indicated that in general male and female students statistically had similar level of anxiety. However, by looking at the types of anxiety, male and female students had a significant difference on cognitive anxiety $(F=8.552, p=.004)$ but remained similar on somatic anxiety $(F=2.311, p=.130)$ and avoidance behaviour $(F=.000, p=989)$. In addition, students studying at lower-secondary school, upper-secondary school and university were also observed to have similar level of anxiety. Although, the ANOVA calculation resulted that students studying at secondary schools and university statistically had similar level of anxiety on somatic anxiety $(F=.125, p=.882)$ and cognitive anxiety $(F=.025, p=.975)$.

\section{Students' Types of Foreign Language Writing Anxiety across Gender and Educational Levels}

Table 6 below presents the descriptive statistics of students' somatic anxiety, avoidance behaviour and cognitive anxiety, showing that the mean score and the standard deviation of the anxiety types is comparable across gender and educational background, except that female students experienced cognitive anxiety more than males.

\section{Table 6}

Students'type of foreign language anxiety based upon their gender and educational levels

\begin{tabular}{llllllll}
\hline & & \multicolumn{3}{c}{ Gender } & \multicolumn{3}{c}{ Education } \\
\cline { 4 - 8 } & & & Male & Female & LS & US & U \\
\hline \multirow{2}{*}{ Somatic Anxiety } & $M$ & 20.97 & 20.23 & 21.46 & 21.28 & 21.31 & 20.93 \\
& $S D$ & 5.36 & 5.7 & 5.01 & 4.97 & 5.54 & 5.2 \\
Avoidance Behaviour & $M$ & 25.68 & 21.51 & 21.52 & 22.52 & 22.58 & 20.1 \\
& $S D$ & 6.05 & 5.05 & 4.45 & 4.72 & 4.51 & 4.22 \\
Cognitive Anxiety & $M$ & 21.51 & 23.7 & 26.38 & 25.72 & 25.55 & 25.76 \\
& $S D$ & 4.59 & 6.41 & 5.78 & 5.57 & 6.62 & 6.03 \\
\hline
\end{tabular}

To examine the extent to which each item in the SLWI subscale contributes to students' writing anxiety, item separation of the SLWAI inventory was evaluated. As shown in Table 2 earlier, the index of item separation was 7.16 (rounded to 7), which classified the inventory items into seven strata. The seven group items were developed by dividing the item logit distribution into seven equal parts. Specifically, the stratification process of the logit values employed the percentile values of $14.28,28.57,42.86,57.14,71.43$, and 85.71 , respectively. The following table 7 below details the category of items based upon their logit value items (LVI) and figure 1 presents the person-map from the data. 
Herri MULYONO, Anggi Rizky LIESTYANA, Silih WARNI, Gunawan SURYOPUTRO, Sri Kusuma NINGSIH. Indonesian students' anxiety to write in English as a foreign language across gender and educational levels

PROBLEMS

OF EDUCATION

IN THE $21^{\text {st }}$ CENTURY

Vol. 78, No. 2, 2020

Table 7

The category of items based upon their logit value item (LVI)

\begin{tabular}{|c|c|c|}
\hline Category & Criteria & Subscale / Item / LVI \\
\hline \multicolumn{3}{|c|}{ More difficult to experience } \\
\hline Difficulty Strata I & $.73<$ LVI & $\begin{array}{l}\text { SA I19 (LVI }=1.31) \\
\text { AB I18 (LVI }=.77) \\
\text { AB I12 (LVI }=.74)\end{array}$ \\
\hline Difficulty Strata II & $.4 \leq \mathrm{LVI} \leq .73$ & $\begin{array}{l}\text { AB I22 (LVI = .73) } \\
\text { SA I6 (LVI = .5) } \\
\text { CA I20 (LVI = .43) }\end{array}$ \\
\hline Difficulty Strata III & $.2 \leq \mathrm{LVI} \leq .4$ & $\begin{array}{l}\text { SA I15 (LVI = .39) } \\
\text { CA I1 (LVI = .3) } \\
\text { AB I10 (LVI = .26) }\end{array}$ \\
\hline \multicolumn{3}{|c|}{$\begin{array}{l}\text { Moderate level of difficulty to } \\
\text { experience }\end{array}$} \\
\hline Difficulty Strata IV & $-.2 \leq \mathrm{LVI} \leq .2$ & $\begin{array}{l}\text { SA I8 (LVI = .2) } \\
\text { CA I14 (LVI =.17) } \\
\text { AB I16 (LVI = .01) } \\
\text { CA I17 (LVI = -.16) }\end{array}$ \\
\hline \multicolumn{3}{|l|}{ Easer to experience } \\
\hline Difficulty Strata V & $-.43 \leq \mathrm{LV} \leq .2$ & $\begin{array}{l}\text { SA I11 (LVI }=-.31) \\
\text { SA I13 (LVI }=-.4) \\
\text { CA I7 (LVI }=-.42)\end{array}$ \\
\hline Difficulty Strata VI & $-.6 \leq \mathrm{LV} \leq-.43$ & $\begin{array}{l}\text { CA I21 (LVI = - .45) } \\
\text { SA I2 (LVI = - .47) } \\
\text { CA I3 (LVI = - .59) }\end{array}$ \\
\hline Difficulty Strata VII & $\mathrm{LV} \leq-.6$ & $\begin{array}{l}\text { CA I9 (LVI }=-.64) \\
\text { AB I4 (LVI }=-.66) \\
\text { AB I5 (LVI }=-.73)\end{array}$ \\
\hline
\end{tabular}


Herri MULYONO, Anggi Rizky LIESTYANA, Silih WARNI, Gunawan SURYOPUTRO, Sri Kusuma NINGSIH. Indonesian students' anxiety to write in English as a foreign language across gender and educational levels

\section{Figure 1}

Item-person Wright map

$\mid$\begin{tabular}{l} 
PROBLEMS \\
OF EDUCATION \\
IN THE 21 $1^{\text {st }}$ CENTURY \\
Vol. 78, No. 2, 2020 \\
\hline 257
\end{tabular}

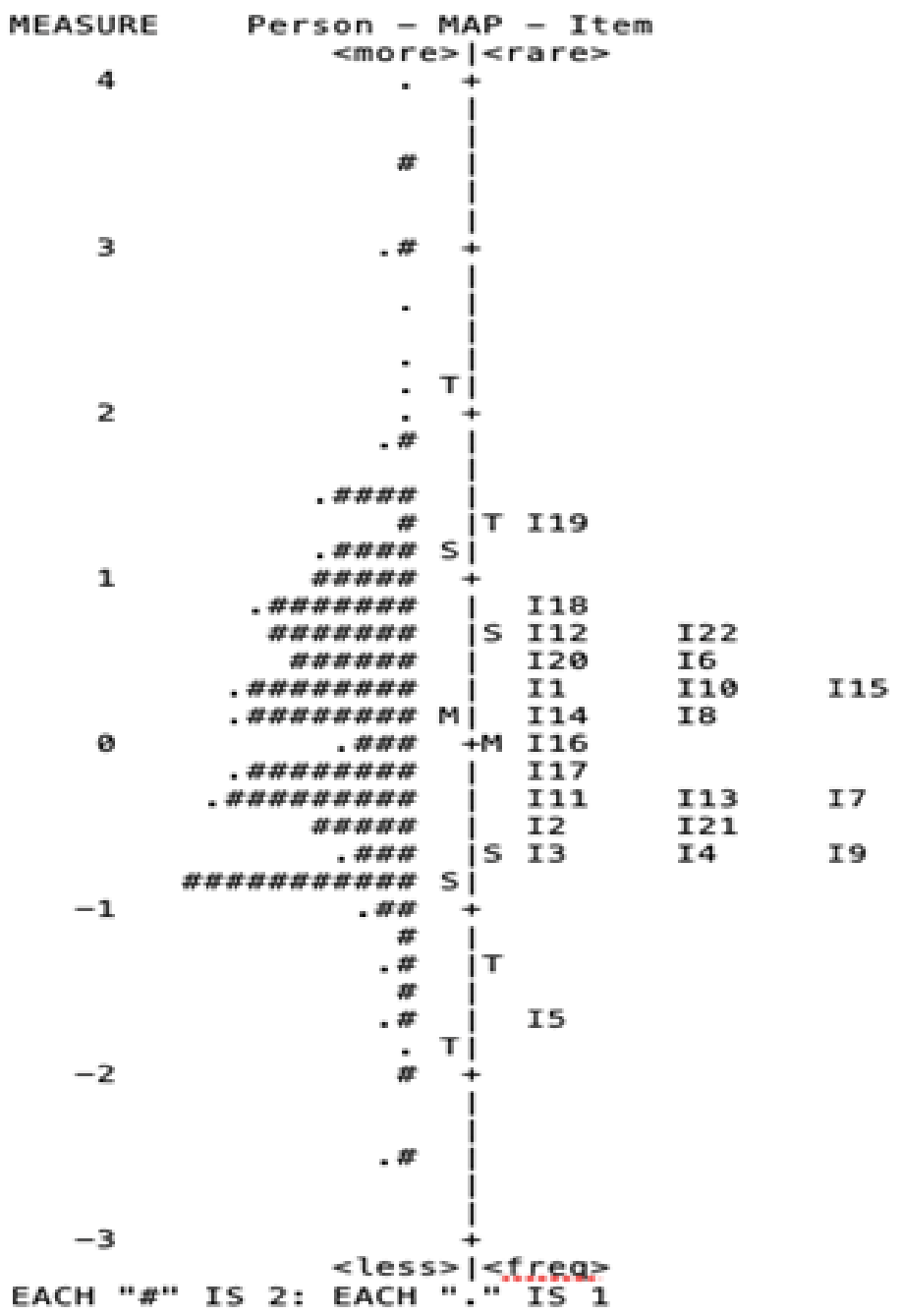

As shown in Figure 1, most students experienced 'avoidance behaviour', when '[they] usually do at [their] best to avoid writing in English composition' (item I5, LVI $=-1.73$ ) and/ or choosing to write their thoughts in English (item I4, LVI $=-.66$ ). The current study also revealed that students felt anxious about writing evaluation and attainment. In the current study, students experienced anxiety when teachers evaluated their English composition and gave a low score (item I9, LVI $=-.64$ ).

To examine if each item was influenced by gender and students' educational background, Person-Differential Item Functioning (DIF) was evaluated and the results are presented in the following Figure 2. 
Herri MULYONO, Anggi Rizky LIESTYANA, Silih WARNI, Gunawan SURYOPUTRO, Sri Kusuma NINGSIH. Indonesian students' anxiety to write in English as a foreign language across gender and educational levels

PROBLEMS

OF EDUCATION IN THE $21^{\text {st }}$ CENTURY Vol. 78 , No. 2, 2020

Figure 2

Person DIF Plot for gender and educational levels

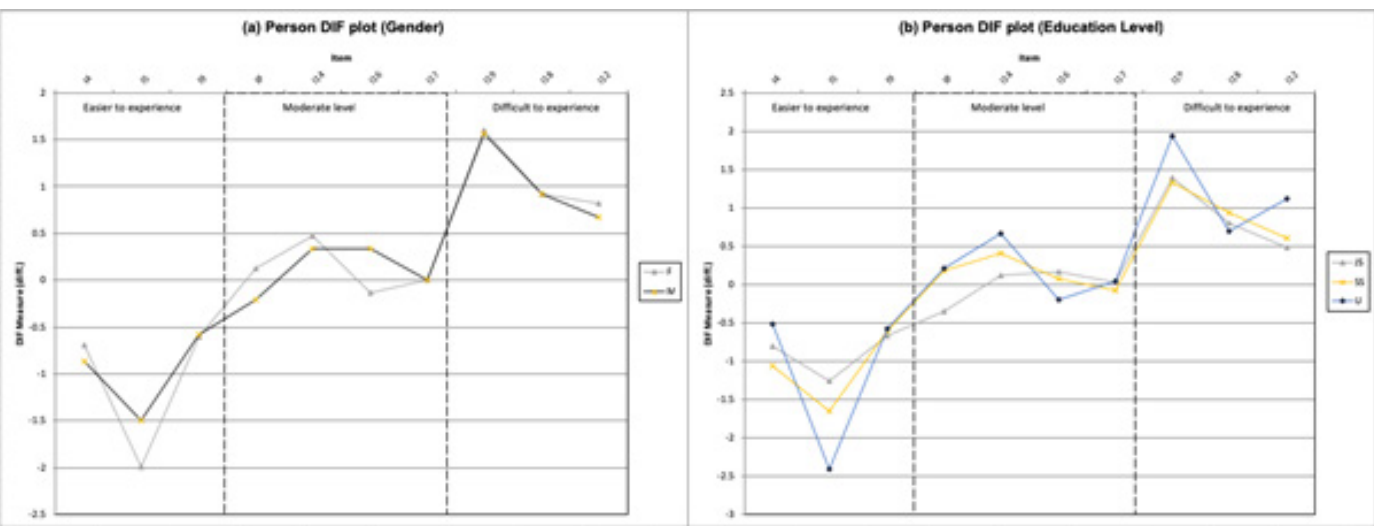

Note: $\mathrm{F}=$ female, $\mathrm{M}=$ male, $\mathrm{LS}=$ lower-secondary school, $\mathrm{US}=$ upper-secondary school, and $\mathrm{U}=$ university

Figure 2 shows that female students tended to do their best to avoid writing in English (DIF value $=-1.99)$ than males (DIF value $=-1.50$ ). Regarding education levels, university students experienced such an avoidance behaviour more frequently (DIF value $=-2.40$ ) than upper-secondary school students $($ DIF value $=-1.65)$ and lower-secondary school students (DIF value $=-1.26$ )

Furthermore, average students shared their experience of 'feeling worried about what other people would think about their English' (item I17, LVI $=-.16$ ), 'doing [their] best to find excuses if asked to write English composition' (item I16, LVI = .01), 'being afraid if other students would deride their English composition if they read it' (item I14, LVI $=.17$ ) and 'trembling when they write English composition under time pressure' (item I8, LVI $=.2$ ). The finding is in reference to an earlier study by Özkan and Da (2015) who revealed that time constraints had restricted students from exploring their thoughts in FL. Özkan and Da (2015) also suggest that time constraints can impact on students writing, resulting in grammatical mistakes, inappropriate vocabulary use, and short compositions.

Regarding gender, both male and female students experience cognitive anxiety, especially when under time pressure (DIF value $=.004)$. Interestingly, upper-secondary school students experienced such anxiety in a more constant manner (DIF value $=-.072$ ) compared to those studying in lower-secondary school (DIF value $=.026$ ) and at university (DIF value $=0.039$ ). It is interesting that both male and female students are less experienced of 'feeling their wholebody rigid and tense when they write English composition' (item I19, LVI = 1.31, DIF value $=1.5$ ). Moreover, university students were experiencing a least somatic anxiety rather than students who are studying at lower-secondary school $($ DIF value $=1.392)$ and upper-secondary school $($ DIF value $=1.336)$.

\section{Discussion}

The current study examined whether Indonesian EFL students across gender and education levels experienced writing anxiety in FL and the extent to which these students experienced anxiety in writing English as a foreign language. The findings showed that all students experienced writing anxiety in foreign language learning, many with a moderate level of anxiety. However, students' writing anxiety was not influenced by gender and educational levels, with all students reporting experiencing somatic anxiety, avoidance behaviour and cognitive anxiety. Avoidance behaviour was the most common form of anxiety amongst the 
Herri MULYONO, Anggi Rizky LIESTYANA, Silih WARNI, Gunawan SURYOPUTRO, Sri Kusuma NINGSIH. Indonesian students' anxiety to write in English as a foreign language across gender and educational levels

students. These findings do not completely agree with the previous study by Cheng (2002) and Özkan and Da (2015). Cheng (2002) reported that female students experienced significantly higher levels of second language writing anxiety than males, with no significant difference among students across education levels. While, Cheng evidenced that the increase of students' writing anxiety level was influenced by the increased study time. As suggested by Cheng (2002), helping students to develop a positive perception about their foreign language writing is crucial in addition to helping them develop their writing skills. Furthermore, in Özkan and Da's (2015) study, male students were found to undergo more writing anxiety than female students. The result of their study also revealed that there was no difference in general writing anxiety level between female and male students in FL setting, but they were significantly different on somatic anxiety. Özkan and Da (2015) showed that female students tended to be more deteriorate from somatic anxiety.

One of interesting findings of the current study suggested that although students' levels of anxiety were statistically comparable among education levels, findings of the current study revealed that secondary school students possessed higher anxiety level than the university students. Such a finding was inconsistent with Martinez et al.'s (2011) study suggesting that the requirement of writing essay is frequently applied in university and accordingly, may promote anxiety among university students. This discrepancy could be attributed to Indonesian secondary education system. In the system, the ability to write in an FL is one of primary objectives in the national curriculum and such an ability has been taken as one of the evaluation subjects. In other words, FL writing examination is a prerequisite for graduation from secondary school that students are required to complete. The current study thus has indicated that FL writing examination and its impact on students' overall performance at school may have been the driver of the high level of anxiety among secondary school students.

\section{Conclusions and Implications}

The current study was aimed to explore the level and types of anxiety expressed by Indonesia students in writing in English as a foreign language anxiety across gender and educational levels. The analysis of the quantitative data showed that all students experienced writing anxiety in FL learning, many experiencing a moderate level of anxiety. Furthermore, students' writing anxiety was not statistically influenced by gender and educational levels. Indeed, students across all education levels reported experiencing somatic anxiety, avoidance behaviour and cognitive anxiety, with avoidance behaviour being the most common form of anxiety. In conclusion, it is recommended that helping students to develop a positive perception of their FL writing is crucial in addition to helping them develop their writing skills.

It is also important to acknowledge some limitations of the current research. First, the current research involved a small number of participants for each educational level $(N<100)$ that does not represent the whole population. Second, the current study considered gender and educational background as factors that may influence students' anxiety to write in a foreign language, but their exposure to foreign language as well as their level of English language proficiency may also influence writing anxiety. Therefore, further research could involve a comprehensive study including these four factors which may influence foreign language writing anxiety.

\section{Acknowledgements}

Part of the findings discussed in this paper was presented in ASEAN Comparative Education Network (ACER-N) 2019 and the second International conference on advance and scientific innovation (ICASI) 2019.

\begin{tabular}{l} 
OF EDUCATION \\
IN THE 21 $1^{\text {st }}$ CENTURY \\
Vol. 78, No. 2, 2020 \\
\hline 259
\end{tabular} 
Herri MULYONO, Anggi Rizky LIESTYANA, Silih WARNI, Gunawan SURYOPUTRO, Sri Kusuma NINGSIH. Indonesian students' anxiety to write in English as a foreign language across gender and educational levels

\section{PROBLEMS \\ OF EDUCATION IN THE $21^{\text {st }}$ CENTURY Vol. 78 , No. 2, 2020 \\ References}

Atay, D., \& Kurt, G. (2006). Prospective teachers and L2 writing anxiety. Asian EFL Journal, 8(4), $100-118$.

Awan, R., Azher, M., Anwar, M., \& Naz, A. (2010). An investigation of foreign language classroom anxiety and its relationship with students' achievement. Journal of College Teaching \& Learning, 7(11), 33-40. https://doi.org/https://doi.org/10.19030/tlc.v7i11.249

Basturkmen, H., \& Lewis, M. (2002). Learner perspectives of success in an EAP writing course. Assessing Writing, 8(1), 31-46.

Bekleyen, N. (2009). Helping teachers become better English students: Causes, effects, and coping strategies for foreign language listening anxiety. System, 664-675. https://doi.org/https://doi. org/10.1016/j.system.2009.09.010

Boone, W. J., Staver, J. R., \& Yale, M. S. (2014). Rasch analysis in the human sciences. Springer.

Cheng, Y. (2002). Factors associated with foreign language writing anxiety. Foreign Language Annals, 35(6), 647-656. https://doi.org/https://doi.org/10.1111/j.1944-9720.2002.tb01903.x

Cheng, Y. (2004a). A measure of second language writing anxiety: scale development and preliminary validation. Journal of Second Language Writing, 13, 313-335. https://doi.org/10.1016/j. jslw.2004.07.001

Cheng, Y. (2004b). EFL students writing anxiety: Sources and implications. English Teaching \& Learning, 29(2), 41-62.

Cohen, L., Manion, L., Morrison, K., \& Bell, R. (2018). Research methods in education (8th ed.). London: Routledge.

Daly, J. A. (1978). Writing apprehension and writing competency. The Journal of Educational Research, 72(1), 10-14. https://doi.org/https://doi.org/10.1080/00220671.1978.10885110

Daly, J. A., \& Miller, M. D. (1975). The empirical development of an instrument to measure writing apprehension. Research in the Teaching of English, 9(3), 242-249.

Daud, N. S. M., Daud, N. M., \& Kassim, N. L. A. (2016). Second language writing anxiety: Cause or effect? Malaysian Journal of ELT Research, 1(1), 19.

Ekmekçi, E. (2018). Exploring Turkish EFL students' writing anxiety. The Reading Matrix: An International Online Journal, 18(1), 158-175.

Field, A. (2013). Discovering statistics Using IBM SPSS statistics, 4th Edition. SAGE Publications.

Guneyli, A. (2016). Analyzing writing anxiety level of Turkish Cypriot students. Education and Science, 41(183), 163-180. https://doi.org/10.15390/EB.2016.4503

Gupta, R. (1998). Writing with a different tool. In C. S. Ward \& W. A. Renandya (Eds.), Computers and language learning. SEAMEO Regional Language Center.

Hewitt, E., \& Stephenson, J. (2012). Foreign language anxiety and oral exam performance: A replication of Phillips's MLJ study. The Modern Language Journal, 96(2), 170-189. https://doi.org/https://doi. org/10.1111/j.1540-4781.2011.01174.x

Ho, M. (2016). Exploring writing anxiety and self-efficacy among EFL graduate students in Taiwan. Higher Education Studies, 6(1), 24-39. https://doi.org/10.5539/hes.v6n1p24

Horwitz, E. K., Horwitz, M., \& Cope, J. (1986). Foreign language classroom anxiety. The Modern Language Journal, 70(2), 125-132. https://doi.org/https://doi.org/10.1111/j.1540-4781.1986. tb05256.x

Kline, P. (2013). Handbook of psychological testing. Routledge.

Linacre, J. M. (2018). A user's guide to Winsteps Ministep Rasch-model computer programs (version 4.3.1). https://www.winsteps.com/a/Winsteps-Manual.pdf

Martinez, C., Kock, N., \& Cass, J. (2011). Pain and pleasure in short essay writing: factors predicting university students' writing anxiety and writing self-efficacy. Journal of Adolescenct and Adult Literacy, 54(5), 351-360. https://doi.org/https://doi.org/10.1598/JAAL.54.5.5

Mulyono, H., Ferawati, Sari, R. N., \& Ningsih, S. K. (2019). Factors contributing to EFL students' speaking anxiety. Register, 12(1), 13-27. https://doi.org/http://dx.doi.org/10.18326/rgt.v12i1.1327

Negari, G. M. (2012). Too nervous to write? the relationship between anxiety and EFL writing. Theory and Practice in Language Study, 2(12), 2578-2586. https://doi.org/10.4304/tpls.2.12.2578-2586 
Herri MULYONO, Anggi Rizky LIESTYANA, Silih WARNI, Gunawan SURYOPUTRO, Sri Kusuma NINGSIH. Indonesian students' anxiety to write in English as a foreign language across gender and educational levels

Ningsih, S. K., Narahara, S., \& Mulyono, H. (2018). An exploration of factors contributing to students' unwillingness to communicate in a foreign language across Indonesian secondary schools. International Journal of Instruction, 11(4), 811-824.

Özkan, K., \& Da, G. (2015). An investigation of L2 learners' writing self-efficacy, writing anxiety and its causes at higher education in Turkey. International Journal of Higher Education, 4(2), 57-66. https://doi.org/10.5430/ijhe.v4n2p57

Rezaei, M., \& Jafari, M. (2014). Investigating the levels, types , and causes of writing anxiety among Iranian EFL students: a mixed method design. Procedia - Social and Behavioral Sciences, 98, 1545-1554. https://doi.org/10.1016/j.sbspro.2014.03.577

Wright, T. (2010). Second language teacher education: Review of recent research on practice. Language Teaching, 43(3), 259-296. https://doi.org/https://doi.org/10.1017/S0261444810000030

Wynne, C., Guo, Y. J., \& Wang, S. C. (2014). Writing anxiety groups: A creative approach for graduate students. Journal of Creativity in Mental Health, 9(3), 366-379. https://doi.org/10.1080/1540138 3.2014 .902343

Yan, J., \& Wang, H. (2012). Second language writing anxiety and translation. The Interpreter and Translator Trainer, 6(2), 171-194. https://doi.org/10.1080/13556509.2012.10798835

Received: December 06, 2019

Accepted: March 18, 2020 
Herri MULYONO, Anggi Rizky LIESTYANA, Silih WARNI, Gunawan SURYOPUTRO, Sri Kusuma NINGSIH. Indonesian students' anxiety to write in English as a foreign language across gender and educational levels

PROBLEMS

OF EDUCATION

IN THE $21^{\text {st }}$ CENTURY

Vol. 78 , No. 2, 2020

262

Cite as: Mulyono, H., Liestyana, A. R., Warni, S., Suryoputro, G., \& Ningsih, S. K. (2020). Indonesian students' anxiety to write in English as a foreign language across gender and educational levels. Problems of Education in the $21^{\text {st }}$ Century, 78(2), 249-262. https://doi.org/10.33225/pec/20.78.249

Herri Mulyono

(Corresponding author)
PhD, Senior Lecture, University of Muhammadiyah Prof. DR. HAMKA, Jakarta.

E-mail: hmulyono@uhamka.ac.id

Website: www.uhamka.ac.id

Bachelor, Staff at Scientific Publication Advancement and Support Unit, University of Muhammadiyah Prof. DR. HAMKA, Jakarta.

E-mail: aanggirizky@gmail.com

Website: www.uhamka.ac.id

Silih Warni

PhD, Senior Lecture, University of Muhammadiyah Prof. DR. HAMKA, Jakarta. E-mail: silihwarni@uhamka.ac.id

Website: www.uhamka.ac.id

Gunawan Suryoputro

E-mail: gunawan_suryoputro@uhamka.ac.id

Website: www.uhamka.ac.id

Master degree, Lecture, University of Muhammadiyah Prof. DR. HAMKA,

Sri Kusuma Ningsih

\section{Jakarta.}

E-mail: sri_kusuma@uhamka.ac.id

Website: www.uhamka.ac.id 